\title{
Libraries and Archives in Portugal
}

Dr. Hirsch, Bard College, has twice done extensive research in Portugal, first-in 1937-as fellow of the Alta Cultura, the Portuguese Institute of Higher Learning, then-in 1949-under a grant from the American Philosophical Society in Philadelphia.

$\mathrm{P}$ ORTUGAL is a nation with a very old civilization. Her most famous university, Coimbra, goes back to the thirteenth century. From that time on, the spiritual ideals of the Catholic Church formed the foundation for the education of the Portuguese people. In Portugal, as in Spain, the Reformation did not succeed in destroying the unity of the Catholic outlook. Nor did the enlightenment, which was introduced in Portugal by the Marquis de Pombal in the mid-eighteenth century, change the thinking of the mass of the Portuguese people.

The librarian and scholar will, therefore, not be surprised to find the fields which are stressed by the Church. well represented in the libraries and archives of Portugal. The subject matter of teaching changed, of course, with the times. During the Middle Ages theology and scholasticism ranked first. In the age of Humanism ancient languages had a prominent place in education and, thanks to Portugal's great maritime adventures, the sciences were flourishing in the sixteenth century. Medicine was developing fast at the same time; famous Jewish scholars transmitted with success the important Arab knowledge in that field. Nautical geography has played a prominent part in Portuguese scholarship ever since the days of Henry the Navigator, who had founded the first scientific school of this kind in Sagres.

It hardly needs emphasizing that the history of the discoveries is very well represented in most libraries. This includes the missionary activities of the Jesuits in the New World. The Portuguese government had closely cooperated with Brazil in preparing modern editions of ancient books which have a bearing on the history of Portugal's former colony. This scholarly enterprise was greatly stimulated by the Congresso de historia dos Descobrimentos e Colonizaçao which was held in Lisbon in 1939. ${ }^{1}$

Most of the well-known libraries in the country possess old collections which were brought together when the Church was wealthy and powerful. It also should be pointed out that the foundations of most libraries in the country go back to collections which once belonged to monasteries when they used to be the centers of higher learning. Most of the larger collections which were once privately owned either by a Church organization or the dynasty have been made accessible to the public. Some of them were transferred to existing larger libraries while others remained independent. One famous example is the library of the exiled late King Manuel II who took his valuable book collection to England. ${ }^{2}$

\footnotetext{
1 Among other institutions the Academia Portuguesa da Historia in Lisboa and Coimbra University have done an excellent job in bringing out new editions of old books and in publishing manuscript material.

${ }^{2} \mathrm{~A}$ catalog of the book collection owned by the late King Manuel II was published in England in three volumes: Os livros Antigos. London, 1929/32.
} 
Several years ago, the books were returned to Portugal after the death of the former King. It was a good idea to keep together the collection, which should be consulted by the student of history concerned with the period of 1480 to 1600 . It may be added here that the student of early Portuguese history should not miss investigating the library of the former palace of Ajuda which is situated on one of the picturesque hills for which Lisbon is famous. ${ }^{3}$

\section{The Libraries of Braga and Svora}

It was a great pleasure to pay a visit to the library in Braga, which is a lively town in the North of Portugal (beyond Porto). Braga has always been the seat of the archbishop-primate of Portugal; as a rule, he was able to stimulate greatly the spiritual activity of the town. In former times, Braga was a famous center for the study of ancient languages. The library, therefore, reflects well the cultural activities of the community in past and present times. It is housed in a magnificent old palace where the archbishop used to live. The present director of the library, Dr. Alberto Feio Soares Azevedo, guided us through the whole building. He called our attention to the many new arrangements for which he is responsible. New shelves have recently been added for the 66,000 volumes of the library, to which the reader has now easy access. The unique collection of manuscripts and incunabula has been carefully put away in drawers where the materials are safe from decay. Dr. Azevedo showed us also with pride the newly decorated lecture hall as well as several private clubrooms which

An important part of the book collection which belonged to the Portuguese dynasty was transferred to Brazil in the nineteenth century.

${ }^{3}$ See Ferreira, Carlos Alberto. Inventario dos manuscritos da Biblioteca da Ajuda referentes a America do Sul. Coimbra, r946. See also the review of the book by Manuel S. Cardozo in the Hispanic American Historical Review, 29:444, August 1949. meet the needs of the many cultural organizations in Braga.

The counterpart to Braga in the south of Portugal is Evora, the charming capital of the lovely province of Alentejo. Monuments of ancient times, among them the impressive ruins of a Roman temple, remind the visitor of Evora's long cultural history. In the sixteenth century Cardinal Henrique chose Evora as the seat of a Jesuit university (against the lively protests from Coimbra) which flourished for a rather short period. The student of the history of the Middle Ages and subsequent centuries will discover a wealth of material in the public library here which includes many important manuscripts. It was a pleasant surprise to find the rich collection well organized and ably supervised by a young, active director. ${ }^{4}$

These few names of libraries which do not belong to an institute of higher learning and which sometimes are located in a less known place may suffice to make it clear that the material for the student of history in Portugal is widely dispersed.

\section{The Collections of Coimbra}

The libraries which are connected with the universities (Lisbon, Coimbra, and Porto) distinguish themselves by especially rich and valuable collections. It is not without a friendly smile that the foreigner observes the rivalry which exists between the University of Lisbon and the University of Coimbra. One is somehow reminded of the gentle feud between Harvard and Yale or Oxford and Cambridge. However, since Coimbra is the oldest university, it should not hurt the feelings of Lisbon if we speak about the libraries and archives of Coimbra first. Moreover, Coimbra is the university

1 Some detail about the available manuscripts can be found in Fr. Stegmuller's "Zur Literaturgeschichte der Philosophie und Theologie an den Universitaten Evora und Coimbra im XVI. Jahrhundert." In Spanische Forschungen, Erste Reine, Bd. 3, I93 I. 
town of the country where the students in their long black capes dominate completely the life of the charming community.

One may climb up through narrow winding streets until one reaches the top of the hill where the old university campus is located. The library building was inaugurated in the eighteenth century. Some of the rooms, where today old books in precious bindings are kept, have still preserved the luxurious decorations which were used at that time. The Biblioteca Geral da Universidade de Coimbra consists all in all of 700,000 volumes. Its foundation was laid by collections which once belonged to convents. The strength of the library, therefore, will be found in publications related to the Middle Ages and the period of the Renaissance and Humanism. The able and energetic director of the library, Dr. Manuel Lopes de Almeida, has done his very best to bring the collection up to date. The library reflects the lively intellectual atmosphere of Coimbra University. Here the student is offered more recent publications than in any other library in Portugal, except for Porto. The reading room is well supplied with reference works which, unfortunately, does not hold true for the National Library in Lisbon. Though the catalog is not meant for the use of the student (a system unfortunately practiced in most libraries in the country), a well-trained staff takes care of finding titles for you.

The archives of the university, which are in a separate building, are the pride of Coimbra. In recent times the university has expanded beyond the limits of its lovely old campus. Outside the gate, which opens on to a view of the rectangular courtyard of the old university, large buildings in modern style have been erected in the last 15 years. Among them is the imposing building of the Arquivo Geral da Universidade.

The director of the archives, Professor
Mario Brandão, a well-known scholar of sixteenth century Humanism, is the extremely active organizer of this model center of archival research. After we had called on him in his luxurious office, decorated with utmost taste (the Portuguese generally excel in good taste), he conducted us on an inspection tour through the large building.

The student from the United States, who is spoiled by the superior technique employed in the libraries and archives at home, should find the archives in Coimbra as up to date as the most modern place he may think of in our country. Elevators lead from the upper floors where the study rooms are located to the basement. Here are the manuscript stacks which are built of concrete and also equipped with a control for the temperature. The house has a central heating system which is not customary in most buildings in Portugal. A curious feature was a built-in gas chamber which destroys the enemy of old papers: the bookworm. The advanced student who is expected to do research here will delight in the modern equipment at his disposal. The scholar will be provided with an attractive study of his own where he can work in tranquillity. The papers have not yet all been put in place, but if this is done the Archives of Coimbra should prove an excellent place for research. ${ }^{5}$

\section{The Libraries of Lisbon}

The contrast will be felt strongly by the foreign observer who visits the National Archives in Lisbon after he has seen the Archives of Coimbra University. It is hard to understand why the government still uses an old-fashioned inadequate building, the Torre do Tombo, which adjoins the House of Parliament, for its most representative archives. The collection is very

Ibid. 
rich and extremely valuable and certainly deserves much better quarters. Many old papers from convents have been transferred there in addition to the vast amount of state papers which naturally came into the possession of the National Archives. The Torre do Tombo has an almost complete collection relating to the Inquisition in Portugal and her colonies. Professor Antonio Baiao, former director of the archives, has already published many documents which are of utmost importance for the history of the Inquisition in his country. $\mathrm{He}$ plans to write a history of the Inquisition in Goa, Portuguese colony in India.

The foreign student, however, will feel somehow frustrated with his work at the Torre do Tombo. It seems that years of patient research are needed if one desires to find some new material. The handwritten catalog, which covers an important part of the manuscripts, the Corpo Cronologico, is nevertheless quite insufficient and has been used by scholars for years, over and over again. There exist other descriptions of the archives but none is able to give a real picture of the material available. The student depends on the suggestions made by members of the staff who are always willing to help but not always trained for that kind of job.

The situation in the National Library in Lisbon is not much better. Its collection consists of 500,000 volumes and 150,000 manuscripts, among them very valuable items. But how is the student to get at them? The handwritten catalog cannot be used by the scholar. At the entrance of the library one receives a paper on which the name of the author and the title of the book desired has to be written. This has to be presented to a clerk who will find the call number from the catalog. $\mathrm{He}$ will hand you a slip of paper with the call number on it which, in turn, has to be shown to an employee in the reading room who will bring you the book. The procedure is utterly discouraging to the scholar. He is deprived of one of his greatest pleasures which consists of the study of the catalog. This, after all, gives him a most valuable chance to discover new titles. How can he be sure of having covered all the material without being able to check with the cata$\log$ ? A subject catalog which is placed in the reading room was started quite a few years ago but is yet far from being completed. The reference works available to the reader are mostly outdated. The foreign student is also surprised by the complete lack of recent publications in the National Library.

The reader who studies rare books has to go to a special Rare Book Room. Here he can at least freely use the handwritten alphabetical catalog. Since an unfortunate theft of valuable material in the Rare Book Room department has been discovered recently, the Government has been looking into the administration of the National $\mathrm{Li}$ brary. It is hoped that, as a result, the service in the library will be greatly improved. Part of the trouble is caused by the fact that the employees are paid extremely low salaries. No well-trained person without private means can afford to accept a job in the library system.

The students of Lisbon University have quite a few special libraries at their disposal. Some, like the Biblioteca da Academia das Sciencias, have rich collections which should be consulted in any case. But neither the student nor the professor can find many books of recent date in any library. I was told by a brilliant young teacher of history at the University of Lisbon that he had made considerable debts in order to buy the books he needs to prepare for his classes. From time to time the large private library of a retired professor comes on the book market, which is welcomed by the young 
scholar as a good opportunity to fill his own book shelves at a reasonable price.

Lisbon was called by Paul Reynaud (French Prime Minister at the time of the Hitler invasion of France) in a brilliant lecture which he delivered in Portugal's metropolis, the "city of poets." Coimbra, on the other hand, prefers to be considered the "brains" of Portugal, while the country's second largest city, Porto, has won fame for her many flourishing industries. Porto should also be praised for her modern public library.

\section{The Public Library in Porto}

Dr. Antonio Cruz, director of the library in Porto, is the only Portuguese librarian to have made an inspection tour of the libraries in the United States. He has introduced many features which our people take for granted in their public libraries but which were unusual until then for the reading public in his country.

I do not remember any library in Portugal which had a periodical room as well equipped as the one in Porto. Nowhere but here were we shown a lovely children's room with a children's librarian in charge of the little crowd. A modern auditorium attracts the citizens of Porto who come in great numbers to attend the lectures organized in regular intervals.
The library of Porto has a valuable old collection of 38,000 books, almost 2,000 manuscripts and 218 incunabula. The kind director showed us the many beautiful examples of illuminate art which the library possesses. It is noteworthy that the alphabetical catalog here can be used freely by everybody. A subject index has been started, but will be completed only in the future. The public library in Porto has well-trained personnel always ready to give advice and to make suggestions.

The foreigner who desires to read in the libraries and archives in Lisbon has to go through a lot of unnecessary red tape. The same does not hold true for other libraries in the country. In most places the visitor will be cordially received. If a fellow librarian introduces himself to one of his Portuguese colleagues, he will be shown all through the house by a most eager director or his representative. The well-known kindness of the Portuguese people finds its expression here also. The librarian from the United States who has paid a visit to Portugal will take home with him the important knowledge of many priceless ancient collections. He will also be favorably impressed by the progress in library organization which has been slowly but steadily made in Portugal, the western-most country of Europe.

\section{Drexel Offers Scholarship}

The School of Library Science, Drexel Institute of Technology, will grant three full tuition scholarships for the academic year 1951-52. The school offers a one-year curriculum leading to the degree of Master of Science in Library Science. The scholarships are awarded to graduates of approved colleges and universities who have achieved high academic standing and are in need of financial aid. Application should be made to the dean of the School of Library Science, Drexel Institute of Technology, 32nd and Chestnut Sts., Philadelphia 4, Penn., before Apr. 15, $195 \mathrm{I}$. 